\title{
The Meaning and Methods of Cost Accounting of Medical College Education
}

\author{
Jinguo Wang \\ Department of Urology \\ The First Hospital of Jilin University \\ Changchun, China \\ wangjinguolily@163.com
}

\author{
Na Wang* (corresponding author) \\ Department of Anesthesiology \\ The First Hospital of Jilin University \\ Changchun, China \\ wangna080613@163.com
}

\begin{abstract}
Setting up and improving the university education cost accounting and management system is the urgent needs of the reform of higher education in our country and an inevitable trend of financial management innovation of colleges and universities. Because it can deliver important information to all parties including managers, investors, government departments in colleges and universities, students and their family and others. It has important significance to realize the sustainable development of colleges and universities. We analyze the literature and the current status of education cost accounting in our country to compare with other countries and areas.
\end{abstract}

Keywords - cost accounting; medical; college education; financial management innovation; sustainable development

\section{INTRODUCTION}

Along with the continuous improvement of the socialist market economic system reform and the deepening of the reform of education system, the financing channels of higher education funds by a single state funding gradually transition to the state, society, educated people of a variety of forms. With the continuous expansion of college education, shortage of funds has become a common problem in colleges and universities. How to correct accounting education cost, controlling unreasonable expenditure and reducing waste, maximize benefits of education funds, establish scientific education cost management mechanism has become a common consensus on the college administrators, many education accounting workers are trying to explore actively, strive to establish a set of effective education cost accounting system of colleges and universities. At present, the education cost accounting theory research stage, there is no unified accounting system and standard, this paper USES the accounting adjustment method in higher medical colleges and schools of education cost accounting, to explore feasible education in order to establish a cost accounting system and standard to provide certain theoretical and empirical basis.

\section{MARKET ECONOMY AND EDUCATION MANAGEMENT}

With the development of market economy and the deepening of the education management system reform, on the one hand, colleges and universities is facing increasingly fierce market competition, must establish the cost consciousness, strengthen internal management, and constantly improve the social benefit and economic benefit of running a school, to occupy the dominant position in the fierce competition. On the other hand, due to begin from 1997, the national colleges and universities implement system charge, higher education into the era of "pay cost to school", personal and family to share the education costs proportion increased significantly compared with the past, the social cost of education in colleges and universities are required to present information on calls for growing [1].

\section{THE IMPORTANCE OF EDUCATION COST ACCOUNTING}

The education cost accounting and management is beneficial to strengthen the financial management of colleges and universities, to optimize the allocation of resources, improve teaching efficiency. Under the condition of planned economy, is only the state administrative department of education subordinate unit of colleges and universities, the lack of corresponding school-running autonomy. Institutions of higher learning in accordance with the plan issued by the state to recruit students, education funding is solved by funding, colleges and universities financial function is a single, usually only accounting spending, regardless of the expenditure efficiency and the cost of education, long-term "at the beginning of the budget, annual final accounts, spending on funding, education cost is not calculation, economic benefits no one tube" reality, cause there are a lot of people, goods, content of enormous waste, formed the lack of higher education resources and waste [2].

Published by the 1998, our country higher education law of the People's Republic of China, make clear a regulation: "institutions of higher learning should be geared to the needs of society, run independently, in accordance with the law, democratic management", in the form of law to determine the main body status of universities, endowed with more autonomy of colleges and universities, and at the same time determines the university "is given priority to with state funding, a variety of other channels to raise higher education funds is complementary" of the education input mechanism, the source of the higher education funds tend to diversification, universities should raise money oriented society, cultivate professional talents to satisfy the needs of the society. Along with our country socialist market economy system establishment and improvement of education as "for the foundation of the national economy development which have 
influence on the overall situation, the origin of industry", has been brought to the priority development of strategic position. The recruitment of students scale expansion of higher education, in particular, has brought the rare development opportunity. While increasing investment in university, must further excavate potential, existing strengthen the management and utilization of education resources, improve teaching efficiency. Education cost is the government which determines the college tuition standard and the important basis of education funds standard.

\section{THE MANAGEMENT OF EDUCATION COST ACCOUNTING}

Higher education belongs to not the obligation. Education, not all people can be in higher education, school-age under the established institutions of higher education opportunity, a person to accept the higher education will reduce the chance to receive higher education, higher education service and production of external economic and consumption of external interests. Therefore, higher education service composition of both private and public products belongs to the quasi-public products. The nature of the higher education service quasipublic products, determines the education costs are shared by the government, society and the educated." Issued by the state council in 1994 (the Chinese education reform and development compendium) of the implementation opinions" clearly put forward that institutions of higher learning and secondary specialized schools, vocational school "shall practice a system of pay cost to go to school. Students pay cost standard by the competent administrative department for education according to embrace a certain proportion of training costs and social and parents bear ability from place to place. In 1996 the former state planning commission, the state education commission, ministry of finance jointly issued the "common colleges and universities charge management method", provides for college tuition fees charged by top shall not exceed $25 \%$ of the training costs. Visible, the cost of education is to identify the important basis of tuition standard. The determination of the government's funding of colleges and universities standard also needs to be based on education cost data.

In the past, the Chinese government funding to take "staffing levels" in colleges and universities on the basis of "base and development model," now is a "comprehensive norm and special subsidy" mode, the two modes are not reflect the actual training school students cost, not scientific way of funding. A growing number of researchers both at home and abroad grant set based on cost.

The higher education law rules issued by our country in 1998: "the education administrative department under the state council in conjunction with other relevant departments under the state council according to the per capital cost of education, students in institutions of higher learning standard expenditure and raise the basic principles of school of different levels and classes, standard and allocation method should be different, reform according to the number of students funding to gradually implement the fund system". In 1999 the third national education work conference, the central committee of the communist party of China and the state council on deepening education reform and comprehensively promote quality education decision "is further proposed that" we will further improve the education funds allocating methods, give full play to the education funding in the role of macroeconomic regulation and control, in the stage of compulsory education, to appropriately increasing the ratio of tuition in training costs, and gradually establish conforms to socialist market economic system and the government public finance system of financial education funding policy and cost sharing mechanism ". Above all, to determine a reasonable financial allocation and tuition standard, must first master the different levels of higher education and the category of the education cost [3].

\section{THE BENEFITS OF EDUCATION COST ACCOUNTING}

The students and parents' right to know the need for education cost accounting, provides the basis of the education cost according to the China statistical yearbook 2000, 1999, urban per capita disposable income of 5854 yuan in China, farmers per capita net income of 2210 yuan, at the same time the public universities this specialized subject of tuition level is 2769 yuan, per capita in urban per capita disposable income of $42.38 \%$, expenditure on education for most families has become a big spending projects. With the payment system of common school, especially in recent years, college tuition level is rising rapidly, since 1998 the university tuition standard, the extent of increase year by year, between its amplitude is $20 \%$ $30 \%$ in 1999, 2000 more surprises most people within, 30\% $50 \%$.As higher education service the students of the buyer (or family), study burden is rising, especially low-income families, education spending has been very heavy family burden. Problem of university tuition has become the focus of the society from all walks of life, students and parents of education service price determination basis - education cost is very concerned about. As education service buyers of students and their parents, they have the right to knowledge of education cost information. Don't practice the education cost accounting, no education cost data, the school will not be able to meet the requirements of students and parents understand the education cost.

\section{THE CONCEPT OF EDUCATION COST}

Education cost concepts belong to the category of economics, economics first in this paper, the cost is the essence of Marx. Cost is discussed in the "das kapital", he writes: "in accordance with the capitalist mode of production in the production of the value of each goods, use the formula to represent is $\mathrm{W}=\mathrm{c}+\mathrm{v}+\mathrm{m}$. If we from the commodity value minus the residual value of $\mathrm{m}$, then the remaining in the goods, just a cost of capital on the factors of production value $c+v$ equivalent or compensation value." Can be seen from the expounds Marx, the cost is the nature of production of goods (or service) the amount of the value of the factors of production. This value need to be compensated, or producers cannot continue production. As a basic concept in the field of economics of education research, education costs between different scholars have not reached a consensus. The concept of education costs is in the early $1960 \mathrm{~s}$ with the economics of education having appeared. The earliest put forward that the word "education cost" is the famous British economist, he is one of the earliest scholars of economics of education. In 1958, 
the British education economist published the cost of education; the education funds as the cost of education, and put forward in 1962, is an effective tool for education management cost accounting system, it can reduce the cost of education, improve the efficiency of the education [4].

\section{THE ECONOMIC VALUE OF EDUCATION}

The famous American economist Theodore Schultz 1,963 published The Economic Value of Education. He puts forward the cost of all elements of "Education" concept, he thought that all elements of education cost consists of two parts, one is the cost of the school to provide Education services, including teachers, administrators, auxiliary teaching staff, school maintain normal operation need spending, as well as The depreciation of our school building, land, etc., but does not include The student canteen has nothing to do with The Education service, accommodation, scholarships, subsidies and other expenditures. Second, the opportunity cost of students goes to school, that is, students go to school because of giving up her job opportunities and loss of income [5].

American economist Cohen in the Education Economics, Economics of Education in the Education of the revenue, cost, and their relationship, Education and economic growth, production and cost function of Education, teachers' salaries and its determinants, Education, finance, and Education programs are analyzed. He put forward the education costs can be divided into two broad categories: direct costs and indirect costs [6]. Cost is mainly schools provide education cost directly, but also has a part is students cost due to school, in addition to tuition, books, and extra for room and board, clothing, transportation to and from school and family.

From the perspective of economic analysis, education cost (the actual cost or economic) is the most suitable for the definition of its opportunity cost it can be used in other best condition to measure the value of. Therefore, the actual cost of education is not only including public education funds, also including the private cost. Their research involved in the composition of the education concept, education costs, education spending, the relationship between education input and output, etc., to further expand the study of the theory of the education cost [7].

In the research of education cost classification is to determine the cost of education standard system, its authority is the basis of education cost measurement and research. According to the classification of education cost burden marked method, especially the regular cost according to the project cost and function arrangement, form a cost matrix, is divided into four direct costs and indirect costs, recurring costs, the cost of capital, this method is easy to carry on the education cost analysis, but this method will be the real cost and opportunity cost as direct costs and indirect costs, capital investment as part of the agency cost, which does not conform to their accounting implications [8]. But there is still no proper use of direct costs and indirect costs concept, and do not reflect the composition and function of the education cost project. Marked by education cost is the actual expenditure classification method, the education cost is divided into social direct cost, individual direct costs and indirect costs 3 classes.
But he will depreciation cost as the opportunity cost is wrong, because depreciation is the actual cost of the fixed assets value, is the financial cost rather than the opportunity cost.

Studies abroad for education costs more, but time earlier. In the United States, the relevant research and practical operation of the university education cost accounting has a history of nearly a century.

Our country academic circles of education cost accounting theory began in the early $1980 \mathrm{~s}$. "Published in the early $80 \mathrm{~s}$ to carry out the" talent "accounting research", put forward to the school as a factory, production personnel shall be made in the factory cost accounting method, accounting to a department, a class, and a student's training costs. In the next ten years, education economics and accounting theoretical workers and practitioners have carried out extensive research and exploration, but most of the research is based on statistical or measure the Angle of education cost, at the theoretical exploration stage, its research results lack of feasibility. Overall, the education cost accounting has no uniform understanding and the scientific and feasible measurement method.

In practical applications, various universities are not systematically conducted education cost accounting, education cost accounting and control in the management of colleges and universities is still a new tool. The basic conclusion is that China higher education cost varies with the scale enlargement of school and gradually decreases with the increase of school student/teacher ratio.

\section{CONCLUSIONS}

Research materials all come from the original database of every unit, fundamentally to ensure the credibility and reliability of the results of the study. For three year for the first time in domestic colleges and universities, the education cost of systematic empirical research, the medical education cost measurement method can help medical colleges clear understanding of the education resources to run the status, found that the education resource allocation problems, to formulates the reasonable education cost control strategy, provide a scientific basis for improving the efficiency of education resources, but also practical and easy to promote. Construction of scientific and practical system of medical colleges and universities education cost measurement technology, to strengthen teachers in cost consciousness and culture quality, forming an inner cost constraints and incentive mechanism, fundamentally restricted departments and units to disorderly competition and the waste of education resources is beneficial to optimizing the structure of cost and value evaluation, control workers and prevent the waste of education resources, improve education resource utilization efficiency, ease the lack of education resources is advantageous to the medical colleges and universities internal implementation to the performance evaluation of units at all levels, a reasonable allocation of education resources. 


\section{REFERENCES}

[1] Jones RF. On the cost of educating a medical student [J]. Acad Med. 720: 200-210, 1997.

[2] Metriot GJ. Costing Methodology[J]. Hongles Publisher. 34-36, 1992.

[3] Rein MF. Defining the cost of educating undergraduate medical students at the University of Virginia[J]. Acad Med. 72(3): 218-227, 1997.

[4] Goodwin MC. A pilot study of the cost of educating undergraduate medical students at Virginia Common wealth University. Acad Med. 72(3): 211-217.1997.
[5] Blewett LA. Measuring the direct costs of graduate medical education training in Minnesota. Acad Med. 76(5): 446-452, 2001.

[6] Vaizey J. the Costs ofEducation[M]. London: Allen and Unwin. 162-163, 1958

[7] Schultz TW. The Economic Value ofEducation[M]. New York: Columbia University Press. 1963.

[8] Cohn E. The Economics ofEducation[M]. Oxford: Pergamon Press. 214217, 1972. 